\title{
Arriving at Your Own Door
}

\section{Jon Kabat-Zinn ${ }^{1}$}

Published online: 31 March 2020

(C) Jon Kabat-Zinn 2020
The time will come

when with elation,

you will greet yourself arriving

at your own door, in your own mirror,

and each will smile at the other's welcome,

and say sit here. Eat.

You will love again the stranger who was your self.

Give wine. Give bread. Give back your heart

to itself, to the stranger who has loved you

all your life, whom you ignored

for another, who knows you by heart.

Take down the love letters from the bookshelf,

the photographs, the desperate notes,

peel your own image from the mirror.

Sit. Feast on your life.

\section{Derek Walcott, "Love after Love"}

By now, in our journey together up to this point, it shouldn't be that hard to recognize that in every moment, we are arriving at our own door. In any and every moment, we could open it. In any and every moment, we might love again the stranger who was ourself, who knows us, as the poem says, by heart.

Ironically, we already know ourselves "by heart" in every sense of those two words, but we may have forgotten that we do. Arriving at our own door is all in the remembering, the re-membering, the reclaiming of that which we already are

Excerpted from The Healing Power of Mindfulness: A New Way of Being by Jon Kabat-Zinn. Copyright (C) 2018 Jon Kabat-Zinn. Published by Hachette Books. All Rights Reserved

\section{Jon Kabat-Zinn}

mindfulness@umassmemorial.org

1 Worcester, MA, USA and belong to and have for too long ignored, having been carried seemingly farther and farther from home, yet at the same time, never being farther away than this breath and this moment. Can we wake up? Can we come to our senses? Can we be the knowing that our awareness already is, and at the same time keep don't know mind and honor the not-knowing? Are they even different?

The time will come, the poet affirms. Yes, the time will come, but do we want it to be on our deathbeds when we wake up to who and what we actually are, as Thoreau foresaw could so easily happen when he said (see Book 1, "Introduction, page xxxiii" for the entire quote) ". . . and not, when I came to die, discover that I had not lived?" Or can that time be this time, be right now, where we are, as we are?

The time will come, yes, but only if we give ourselves over to waking up moment by moment, to coming to our senses moment by moment, and befriending and transcending our own underdeveloped minds. Only if we can perceive the chains of our robotic conditioning, especially our emotional conditioning and our view of who we think we are-peel our own image from the mirror - and in the perceiving, in seeing what is here to be seen, hearing what is here to be heard, watch the chains dissolve in the seeing, in the hearing, as we rotate back into our larger original beauty, as we greet ourself arriving at our own door, as we love again the stranger who was ourself. We can. We can. We will. We will. For what else, ultimately, is there for us to do?

How else, ultimately, are we to be free?

How else, ultimately, can we be who we already are?

How else are we to heal? How else are we to come to terms with things as they are?

And when, oh when, oh when is the moment this will happen?

"The time will come ..." the poet says. Perhaps it already has.

Only ... Donnnno!

Perhaps it is time to practice, to feast on your life - as it is - right now, and now, and now, and now . . . 